TRADE TALK

\section{Cell negotiator}

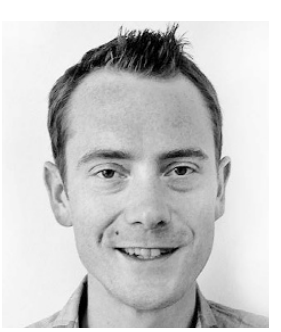

Ben Thiede

is a business-

development officer

at STEMCELL

Technologies in

Vancouver, Canada.

As a neuroscience

graduate student, he

worked out methods

to coax stem cells to

take on specialized properties of the inner ear. Now, he works out intellectual-property and other deals that help to bring technologies to the scientific market.

\section{When did you first think about jobs beyond the bench?}

About two years before I graduated from my $\mathrm{PhD}$ programme at the University of Virginia in Charlottesville, I got married and started thinking more long term about my career. Before that, science was just fun.

\section{What led you to your current career?}

A classmate who was a year ahead of me was graduating with her $\mathrm{PhD}$ and going to law school. She had been exposed to other careers through an internship for the university's licensing and ventures group, working on technology transfer - helping to license and commercialize academic work. I did some informational interviews along the same lines, but I got an internship by talking to a guy who was fitting me for a suit. $\mathrm{He}$ was the father-in-law of one of the licensing managers at the university's patent foundation. I e-mailed the manager, and he took me on.

How did your internship compare to the lab? As a grad student, you think narrowly about one problem. My learning curve in tech transfer was steeper than it was in the lab. I had to quickly pick up what was important about a technology: how does it fit into the field, and what is its value? It was really interesting for me to be close to science that was close to the point of being useful to people.

\section{What do you do now?}

I am looking for technologies, and evaluating whether they work or not and what is already patented. After we negotiate a license to bring in a technology, I can see that in six months or a year we are going to be using it in a product that researchers can buy and use in their labs.

\section{INTERVIEW BY MONYA BAKER}

This interview has been edited for length and clarity. See go.nature.com/xdttdg for more.

\title{
MENTOR MATCH
}

\section{How to get the most out of your dissertation committee}

- Diversify Populate your committee with people who are in your subfield and in related fields. Consider adding members who work at institutions other than your own, or outside academia.

- Communicate early and often Meet privately with your committee members so that you can develop a personal rapport. Check whether they prefer phone, text, e-mail or in-person contact.

- Be honest and clear about your goals and concerns Discuss your professional objectives, such as whether you want to work in academia or industry, move to a different city or nation or pursue a career in science, technology or elsewhere. The

low-income communities. She credits her relationship with the committee member: "That experience changed my life."

Although frequent face time is important, $\mathrm{PhD}$ students should choose at least one committee member who is outside their own institution, says environmental scientist Tammy Newcomer Johnson. That external connection, she says, can help to maximize potential career gains. Her own adviser at the University of Maryland in College Park encouraged her to diversify her committee, and she invited two 'outsiders', including Paul Mayer, an EPA ecologist whom she had met during fieldwork. They discussed career possibilities in the federal government, and Mayer noted links between Newcomer Johnson's doctoral research and the EPA headquarters in Washington DC - where she is now a postdoc.

Thanks to a recommendation from him, she was invited to present a seminar at an EPA lab on monitoring stream restoration. Her talk boosted her CV and led to new contacts in the agency, who in turn gave her more information about research posts there. Now she is mulling over staying with the agency for the long haul. "It gave me a sense of what a scientist does at the EPA - I realized that this could be a really wonderful career path," she says.

Contact with committee members can stretch far beyond those $\mathrm{PhD}$ years, as can the benefits. Kovačević has sat on about 30 dissertation committees; one of her former students turned to her for advice half a dozen years later while pursuing an assistant-dean position at a major US university. Kovačević proofread the CV and suggested improvements. She has also nominated another former student for membership of a prestigious electrical-engineering committee.

Indeed, there is much for a $\mathrm{PhD}$ student to gain from a warm association with more they know about you, the more they can help you.

- Stay in contact Send e-mails, ask for coffee appointments, request short Skype chats and send holiday greetings. - Promote yourself Keep committee members abreast of your progress, successes, challenges and aspirations so that they will keep you in mind for potentially game-changing career opportunities.

- Pay it back Look for ways to help them, too. You have a network and access to information, ideas and opportunities. Work out how you can assist them with their career and professional interests. A.L. committee members, but the best former students will also consider what they can give back. In January, Newcomer Johnson invited members of her former committee to give talks at the EPA. "I'm connecting them with my network," she says. A former student of Kovačevićs landed a desirable position at a company and has since made sure to ask the professor to circulate the company's job openings to her students. "This is a two-way benefit," says Kovačević. "She gets help to succeed at her job, and the benefit to me and my institution is placing students at a good company."

Students should remind faculty members whom they invite to serve on their dissertation committee that they are likely to benefit. "One measure of success for professors is the success of their students," says Claudio. "When you are up for promotion and tenure, the better your students do, the better you look."

In the end, seasoned committee members say, the rewards of a dissertation committee can go both ways. "Understand this is an incredible potential resource," says Kovačević. "Do as much as you can to nurture it."

Alaina Levine is a freelance science writer based in Tucson, Arizona.

\section{CORRECTIONS}

The Careers Feature 'Take my advice' (Nature 532, 531-533; 2016) wrongly implied that the Houston-based consulting club is run by the Texas Medical Center. In fact, it is an independent organization. The Careers Feature 'Change is in the air' (Nature 532, 403-404; 2016) wrongly affiliated climate-change ecologist George Divoky with the University of Alaska Fairbanks. He is actually now director of Friends of Cooper Island in Alaska. 